\title{
Globalization and the Reach of Multinationals Implications for Portfolio Exposures, Capital Flows, and Home Bias
}

\author{
Carol Bertaut \\ Federal Reserve Board
}

\author{
Beau Bressler \\ University of California, Davis
}

Stephanie Curcuru

Federal Reserve Board

\begin{abstract}
The growing use of low-tax jurisdictions as locations for firm headquarters, proliferation of offshore financing vehicles, and growing size, number, and geographic diversity of multinational firms have clouded the view of capital flows and investor exposures from standard sources such as the IMF Balance of Payments and the Coordinated Portfolio Investment Survey. We use detailed, security-level information on U.S. cross-border portfolio investment to uncover the extent of distortions in the official U.S. statistics. We find that nearly a third of U.S. cross border portfolio investment is allocated to a country different from its primary economic exposure by standard reporting conventions. About one-fourth of the stock of global cross-border portfolio investment is similarly distorted, with exposures to emerging markets likely understated by about a third. Estimates of the international exposures of U.S. investors are even larger when we distribute exposure according to the geographic distributions of firm-level sales. Our results have implications for conclusions we draw about the factors influencing capital flows, in particular those to emerging markets.
\end{abstract}

Keywords: balance of payments, capital flows, financial globalization, foreign assets, international financial data, home bias

\section{INTRODUCTION}

The residence-based framework of measuring international exposure is increasingly less informative, as a growing number of firms locate in low-tax jurisdictions and issue securities through offshore subsidiaries. This has clouded the view of capital flows and investor exposures from standard sources such as the IMF Balance of Payments and the Coordinated Portfolio Investment Survey. Recent work has taken steps to address this issue: Bertaut, Bressler, and Curcuru (2019) map security-level data on U.S. investors' cross-border holdings from a residence-basis (where the issuing subsidiary is incorporated, or "resident") to a nationality-basis (reflecting the country of the parent firm) and find that $30 \%$ of the market value of long-term foreign portfolio securities held by U.S. investors in 2017 reflected exposures to countries other 
than as reported in the official U.S. statistics. Coppola, et.al., (2021) map the universe of traded securities to their parent companies and subsidiaries and provide adjustment factors for converting residence-based statistics to a nationality basis. These studies underscore the limitations of the residence-based statistical framework used in official datasets of cross-border positions and capital flows.

However, in a globalized economy even these nationality-based statistics cannot fully capture the true economic exposures of investors. Securities issued by firms with operations around the world will provide exposure to countries other than the country of nationality or residence, as discussed in Cai and Warnock (2012). Indeed, stock prices of internationally-exposed U.S. firms certainly respond to foreign shocks and developments such as dollar appreciation or announcements about potential changes to trade policy such as tariff increases (see, for example, Amiti, Kong, and Weinstein, 2020). In this note we combine securitylevel data on U.S. holdings of common stock with firm-level geographic revenue data to get a fuller picture of the economic exposure of U.S. investors. We then briefly examine some of the implications of this remapping for our understanding of home bias, which is one important driver of cross-border investment.

\section{DATA AND METHODOLOGY}

Our estimates of the geographic exposure of U.S. equity investors consider the full equity portfolio of U.S. investors, including equity of U.S. companies. We start with the annual surveys collected as part of the Treasury International Capital (TIC) system. These data are collected on a legal residence basis for construction of the U.S. International Investment Position. The data on U.S. holdings of stock issued abroad comes directly from the "U.S. Residents Portfolio Holdings of Foreign Securities" survey. U.S. investor holdings of stock issued domestically is inferred from the difference between the total stock market capitalization for each firm (from Worldscope) and the total the amount held by foreign investors as reported in the "Foreign Residents' Portfolio Holdings of U.S. Securities" survey. We then reassign each firm from country of residence to country of nationality using the remapping algorithm of Bertaut, Bressler, and Curcuru (2019). ${ }^{1}$

We then take this remapping of equity holdings from the country of residence to nationality one step further and remap equity holdings based on the geography of firm revenue. Our data on firms' geographic revenue distribution comes from Worldscope. ${ }^{2}$ This is a challenging exercise, because geographic segment descriptions reported to Worldscope are non-standardized and often refer to regions rather than individual countries. When revenue is allocated to a region, we allocate revenue to the component countries of each region based on each country's GDP weights in each region. ${ }^{3}$ Overall, Worldscope coverage for firms in the U.S. equity portfolio (especially for U.S.-listed firms) is quite good, and improves over time. We are able to classify market capitalization and U.S. portfolio holdings for December 2003 through 2018. By 2018, we have data on nearly 9,200 firms with market capitalization at end-2018 of $\$ 68$ trillion. $^{4}$

\section{REVENUE-BASED ESTIMATES OF U.S. EQUITY EXPOSURE}

Figures 1a, 1b, and 1c compare total U.S. portfolio holdings on a residence, nationality, and revenue basis. On a residence basis, holdings of domestic equities amount to about \$21 trillion in December 2018 (Figure 1a), roughly 80 percent of the total equity holdings of U.S. investors of about $\$ 27$ trillion. Domestic holdings are slightly higher on a nationality basis, increasing to $\$ 21.8$ trillion (Figure 1b), reflecting our reclassification of $\$ 800$ billion in holdings of equity of U.S. multinationals incorporated in offshore centers.

Holdings of emerging market equity are also slightly larger, in large part reflecting the reclassification of financial center equity to China (see Bertaut, et.al., 2019). 
FIGURE 1A

\section{U.S. HOLDINGS OF COMMON STOCK, RESIDENCE BASIS}

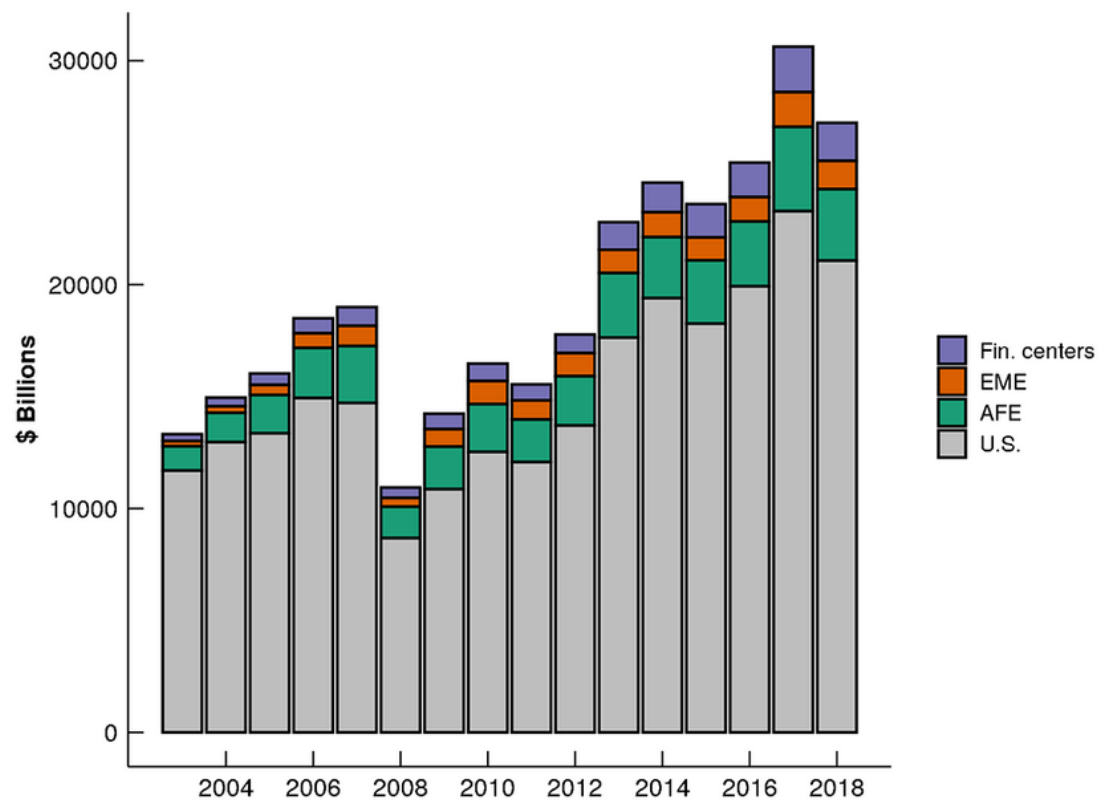

FIGURE 1B

U.S. HOLDINGS OF COMMON STOCK, NATIONALITY BASIS

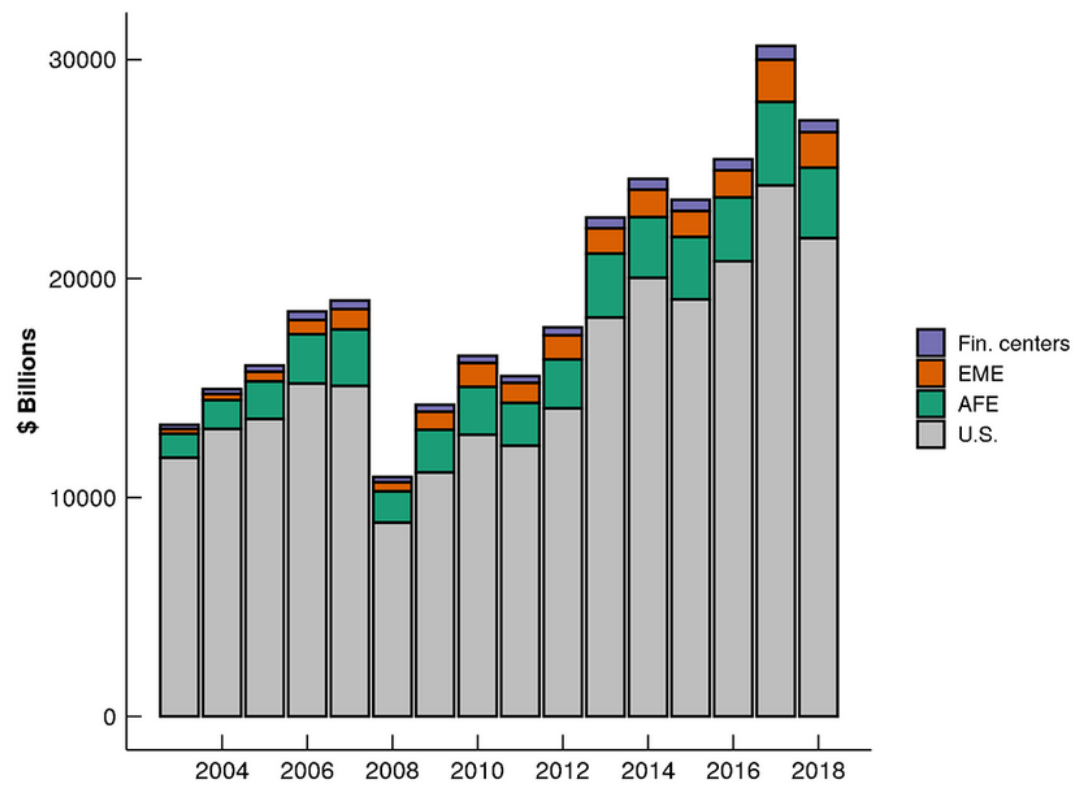




\section{FIGURE 1C \\ U.S. HOLDINGS OF COMMON STOCK, REVENUE-EXPOSURE BASIS}

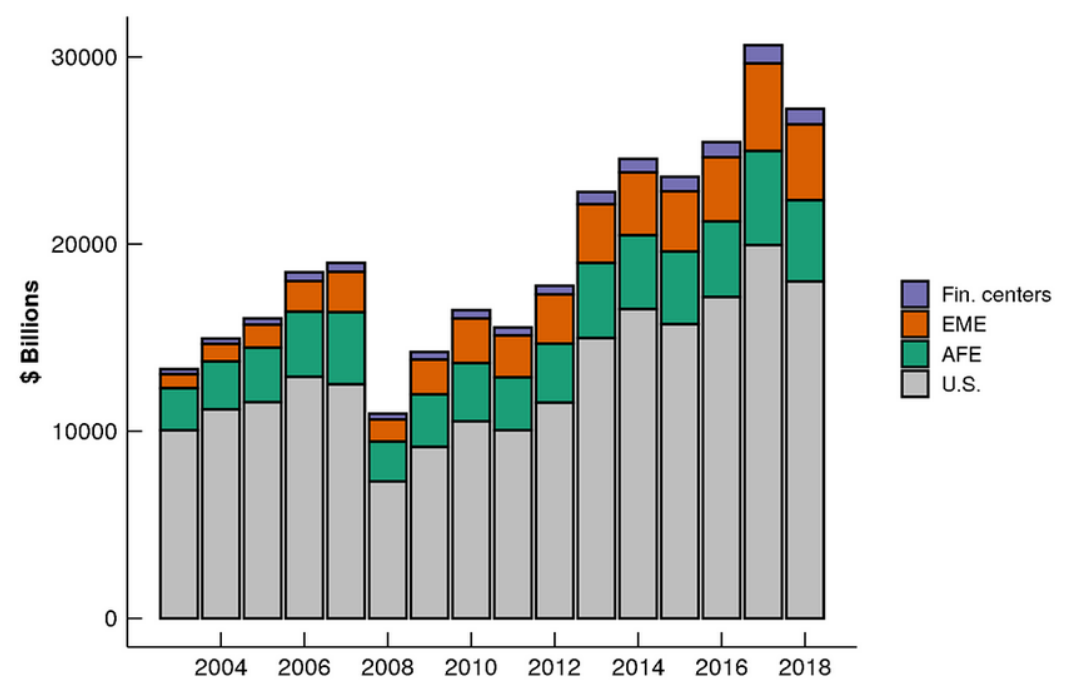

Source: Treasury International Capital System; Bloomberg; Refinitiv Worldscope Fundamentals; Authors' calculations.

Our remapping using the geography of firm revenue presents a much different picture of U.S. investor exposure. On a revenue basis, domestic equity holdings remain the largest portion of the total portfolio but fall to $\$ 18$ trillion (figure 1c). This smaller U.S. exposure reflects the fact that large-cap U.S. firms have substantial revenue from global sources and thus holding their shares provides U.S. investors with considerable exposure to other countries. Of course, the reduced exposure to the United States and increased exposure to the rest of the world is partially offset by a reallocation of some of the holdings of foreign equity: Foreign multinationals often generate significant revenue from U.S. sales, and thus U.S. investors acquire some U.S. exposure through their holdings of foreign stocks. The differences in geographic allocations between the revenue-based statistics and the residence- and nationality-based statistics are shown in figures $2 \mathrm{a}$ and $2 \mathrm{~b}$, respectively. In the early part of our sample, most of the reallocation from domestic to foreign exposure was to other developed countries. In more recent years, however, most of the remapping has been to emerging market economies. 
FIGURE 2A

\section{U.S. HOLDINGS OF COMMON STOCK, DIFFERENCE BETWEEN REVENUE-EXPOSURE AND RESIDENCE BASIS}

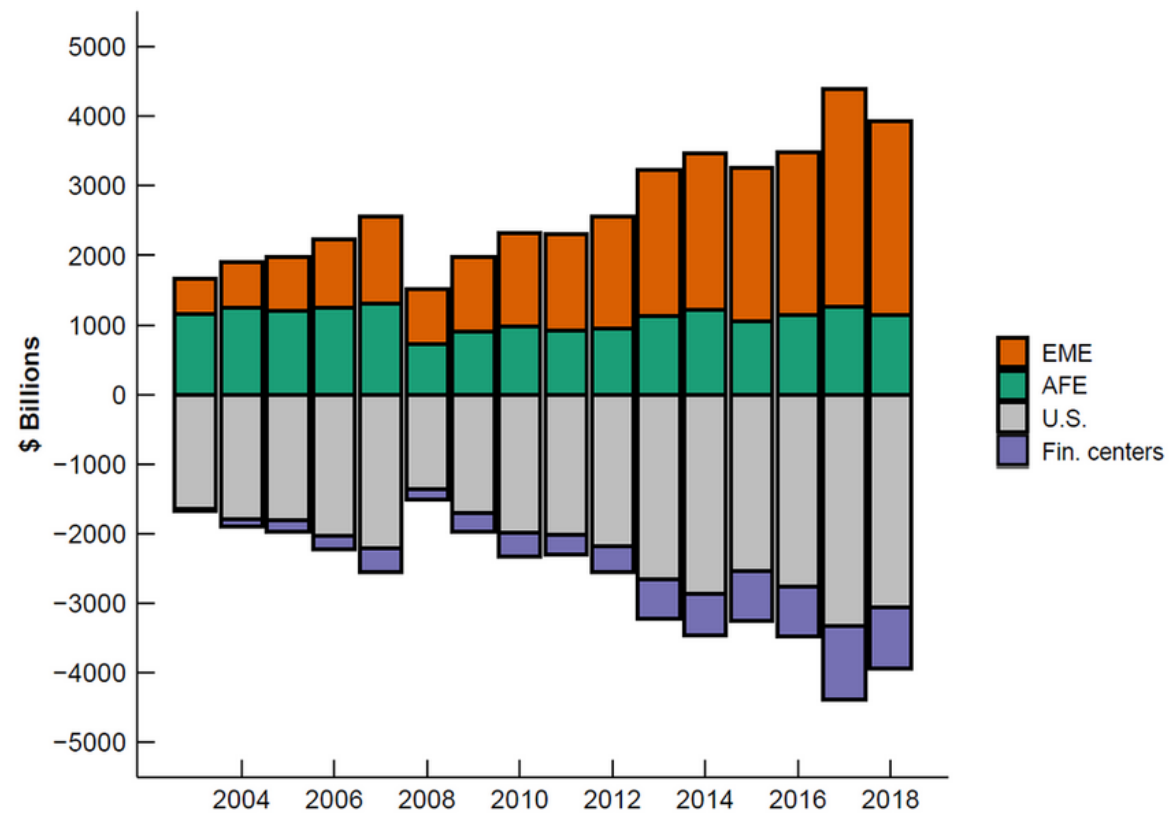

FIGURE 2B

U.S. HOLDINGS OF COMMON STOCK, DIFFERENCE BETWEEN REVENUE-EXPOSURE AND NATIONALITY BASIS

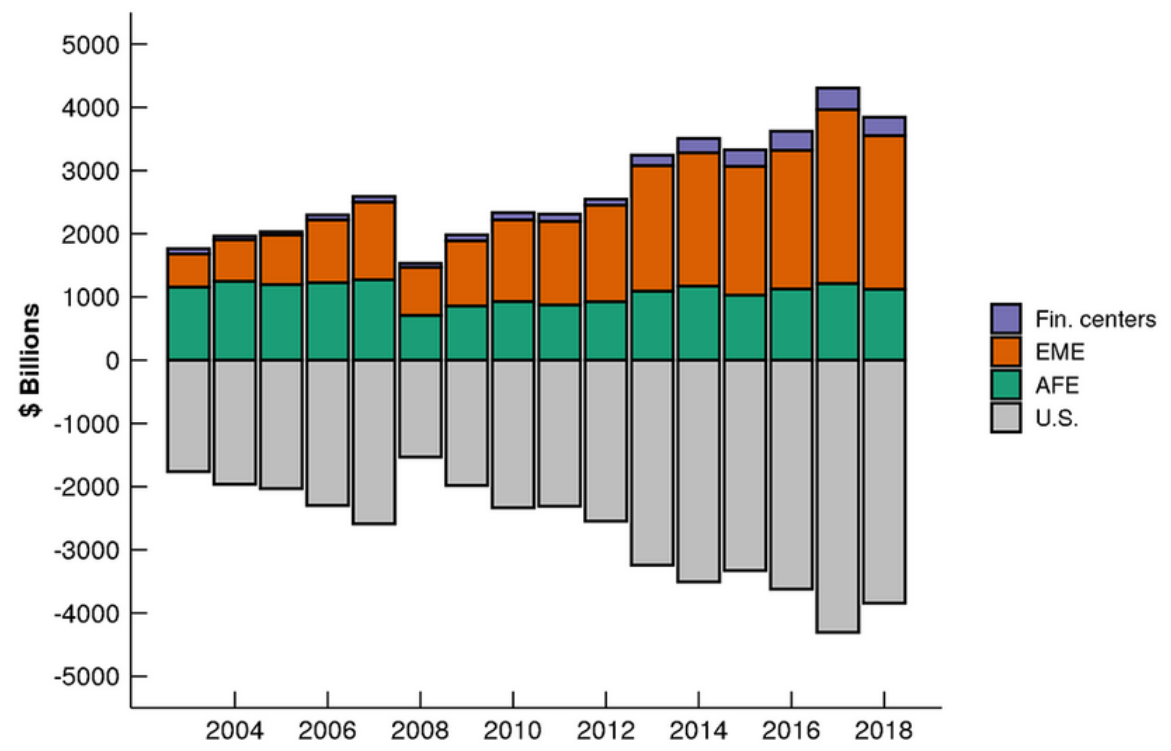

Source: Treasury International Capital System; Bloomberg; Refinitiv Worldscope Fundamentals; Authors' calculations.

Two particularly striking facts stand out from the revenue-based holding estimates. First, we find that U.S. investors may have as much indirect foreign exposure from their holdings of equity of U.S. multinationals as from direct holdings of foreign equity. The sources of the domestic and foreign exposures 
of U.S. investors are shown in Figure 3. In December 2018, U.S. investors had \$4.6 trillion of foreign exposure from their holdings of U.S. equity, almost as much as their $\$ 4.8$ trillion of foreign exposure from their direct foreign equity holdings.

FIGURE 3

\section{U.S. HOLDINGS OF COMMON STOCK, REVENUE EXPOSURE BASIS BY TYPE OF ECONOMY AND NATIONALITY OF FIRM}

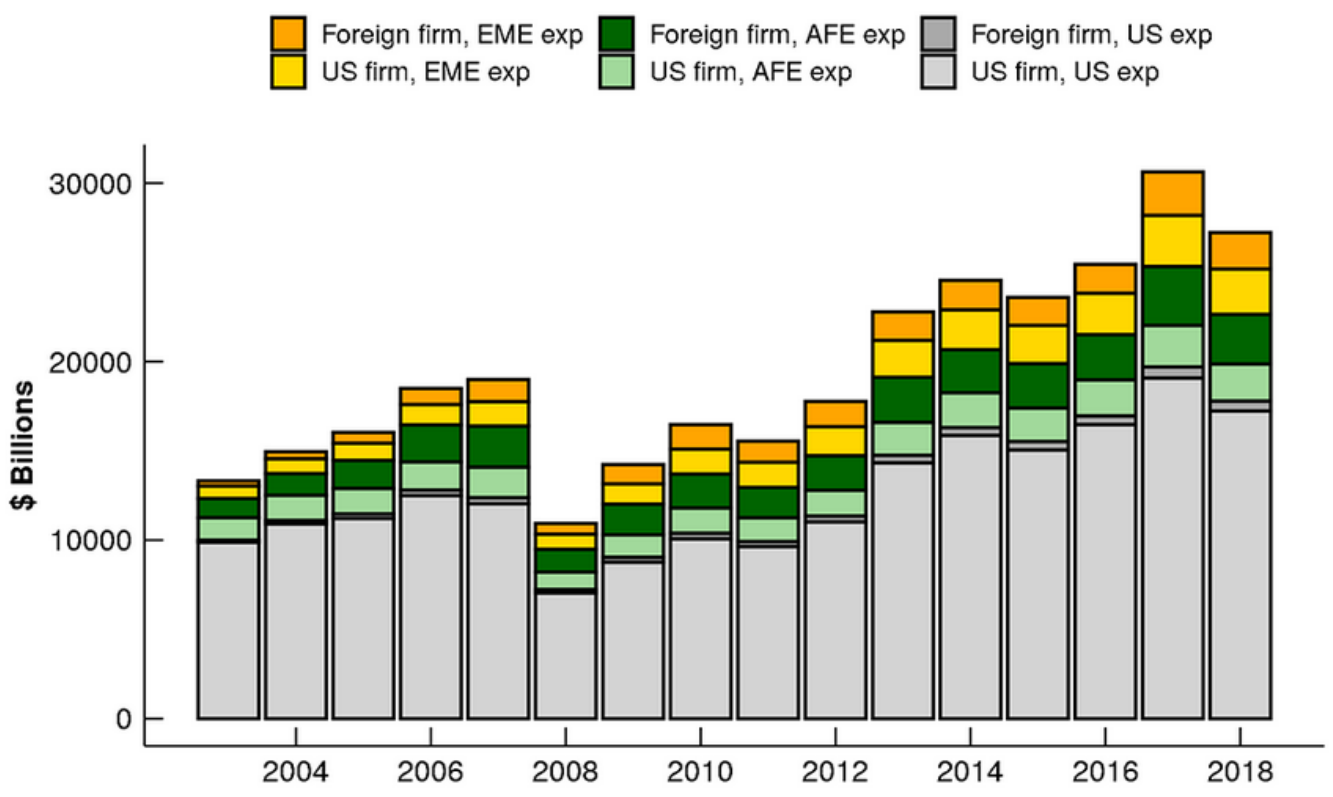

Source: Treasury International Capital System; Bloomberg; Refinitiv Worldscope Fundamentals; Authors' calculations.

Second, we find that U.S. investors have about as much exposure to emerging markets as they do to advanced foreign economies, as multinational firms generally have significant exposures to emerging markets. In 2018, U.S. investors had \$4.6 trillion in emerging market exposure, including \$2.5 trillion through U.S. holdings of domestic multinationals, versus $\$ 4.9$ trillion of advanced economy exposure.

\section{IMPLICATIONS FOR HOME BIAS}

Our results have implications for a wide range of topics of interest to global policy makers and academics. These include conclusions we draw about the factors influencing capital flows, in particular those to emerging markets, and the drivers of international investment allocations more generally. For instance, one long-standing puzzle in the international finance literature is investor "home bias"; in other words, the lack of diversification of international investors relative to the optimal holdings implied by the International Capital Asset Pricing model (ICAPM). The ICAPM predicts that in a world with frictionless markets the optimal asset allocation is the world portfolio; in other words, investors should spread their wealth among global equities according to each asset's share of global market capitalization. For example, since U.S. equities currently make up about 40 percent of global market capitalization, about 40 percent of U.S. investors' equity holdings should be in U.S. stocks.

The usual estimate for the degree of home bias in investor portfolios compares portfolio allocations in foreign (to the investor) equity to shares in global market capitalization: 
Home Bias $=1-\frac{\frac{(\text { holdings of foreign equity) }}{\text { (total equity portfolio })}}{\frac{\text { (foreign equity market cap })}{\text { (world equity market cap })}}$

Note that if portfolio shares are close to or equal market capitalization shares, the ratio in the second term of equation (1) will be close to one. Thus, the ratio is typically subtracted from 1 to measure "home bias", so that the larger this resulting calculation, the greater the extent of home bias. A home bias of 0.5 means that investors hold half as much foreign stock (or twice as much domestic stock) as implied by the ICAPM.

In practice, investors in the U.S. hold larger shares of their wealth in domestic securities than predicted by the ICAPM, and this is true for investors around the globe. There is a large literature on the potential causes of home bias, which include hedging motives arising from exchange rate and other risks, and frictions such as transactions costs as well as easier access to and better information about domestic markets. Coeurdacier and Rey (2013) provide a comprehensive survey of this literature. This literature focuses on factors that affect investor demand for exposure, and the associated characteristics of investment in different countries. But how these portfolio shares - and market capitalization shares - are constructed can lead to markedly different measures of home bias, which in turn can confound our interpretation of what drives portfolio preferences.

Figure 4 shows our home bias estimates for U.S. investors. When holdings are measured by residence, home bias in common stock is quite high. That said, it has trended down slightly from about 0.75 in the early 2000s to about 0.65 after the global financial crisis, and it has remained around that level for the past several years. When instead holdings measured on a nationality basis, home bias is even higher, largely due to holdings of firms in financial centers that we remap to the United States. Home bias estimates are notably lower when holdings are revenue-based, generally below 0.5 . This lower level of home bias largely reflects the additional exposure to foreign countries that U.S. investors achieve through their holdings of equity of U.S. multinationals.

\section{FIGURE 4 \\ U.S.HOME BIAS IN COMMON STOCK}

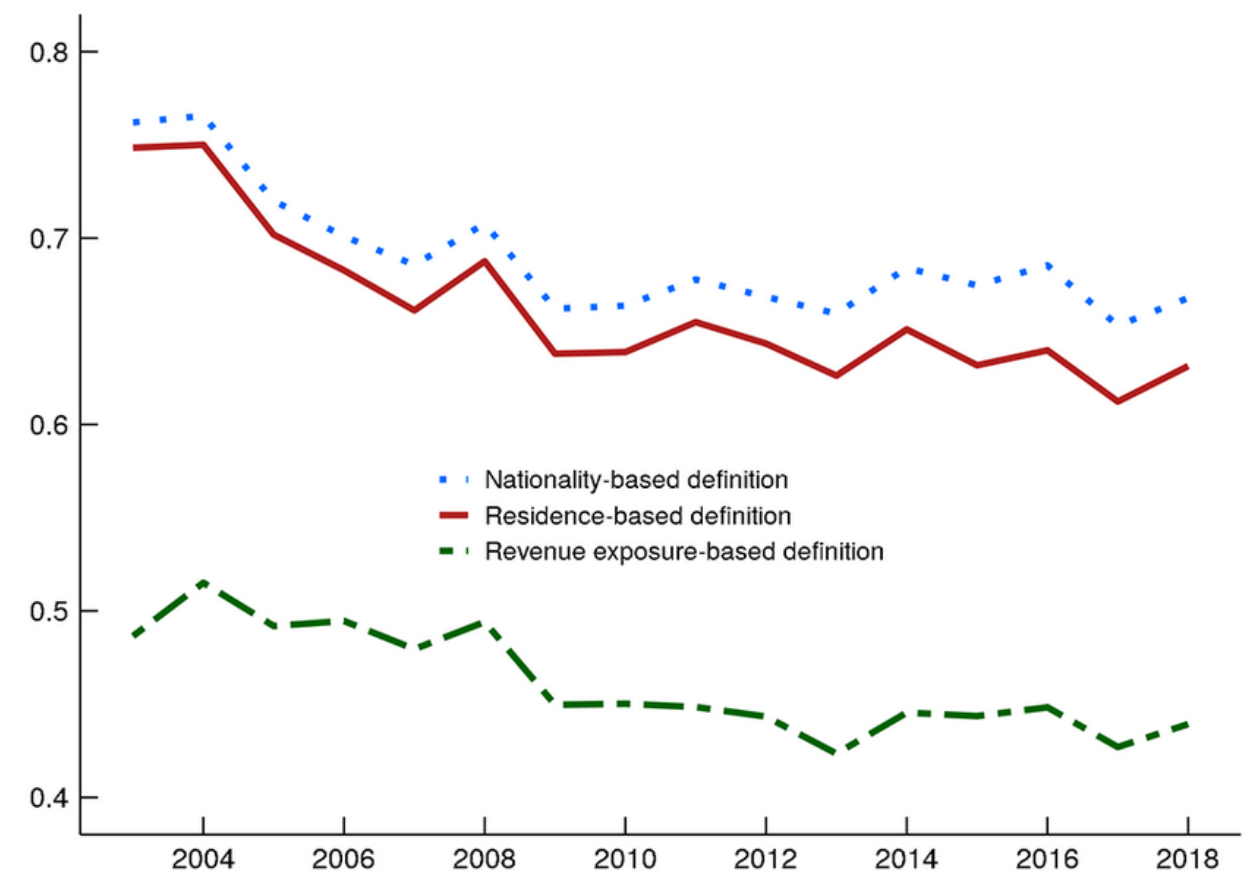

Home bias estimates from equation (1) for alternative measures of holdings of foreign equity. 
The marked differences in home bias magnitudes and trends across measures suggests caution is needed when constructing home bias estimates using aggregate data such as the IMF's Coordinated Portfolio Investment Survey (CPIS). The CPIS is collected on a residency basis, and as our analysis shows, holding shares of multinational firms can considerably increase the measured global exposure of a country's investors. Our investigation of the U.S. portfolio indicates that U.S. home bias clearly still exists, but estimates of the magnitude of the bias are notably lower when calculated on a revenue-exposure basis.

We can further illustrate the portfolio diversification effects of investment in multinational firms using the relative portfolio weight measure introduced in Ahearne et.al., (2004):

$$
\text { Relative Portfolio Weight } t_{i}=\frac{\frac{(\text { holdings of country i equity) }}{\text { (total equity portfolio) }}}{\frac{\text { (countryi equity market cap) }}{\text { (world equity market cap) }}} \text {. }
$$

Table 1 presents descriptive statistics for the relative portfolio weights of the U.S. investor foreign portfolio with country holdings estimated alternatively by residence, nationality, and revenue-exposure. Averaged across foreign countries, country weights are about 0.25 on both a residence and nationality basis, but there is considerable heterogeneity: For both measures, estimates range from close to zero, indicating almost full "country bias", to more than 1, indicating that U.S. investors actually hold more than the market capitalization share in a few countries. Consistent with our finding of lower overall home bias on a revenueexposure basis, revenue-based portfolio weights are generally larger than are either the residence- or nationality-based weights, though these too show considerable heterogeneity. The residence- and nationality-based weights are highly correlated with each other, as would be expected given that the nationality reassignments primarily affect the handful of financial center countries. Their correlations with the revenue-exposure based weights are notably lower.

\section{TABLE 1}

\section{DESCRIPTIVE STATISTICS, U.S. INVESTOR COUNTRY-LEVEL RELATIVE PORTFOLIO WEIGHTS}

\begin{tabular}{lccc}
\hline Portfolio weight & Residence Basis & Nationality Basis & Revenue-Exposure Basis \\
\hline Mean & 0.248 & 0.238 & 0.570 \\
Standard deviation & 0.240 & 0.206 & 0.188 \\
Minimum & 0.001 & 0.001 & 0.081 \\
Median & 0.203 & 0.205 & 0.554 \\
Maximum & 1.570 & 1.435 & 1.370 \\
$\mathrm{~N}$ & 861 & 861 & 861 \\
Correlation with Nationality & 0.915 & & \\
Correlation with Revenue- & 0.419 & 0.373 & \\
Exposure & & &
\end{tabular}

Statistics on relative portfolio weights from equation (2) for alternative measures of holdings of foreign equity over 2004-2017.

These ICAPM-based measures of home bias omit factors widely acknowledged to also influence portfolio preferences. To capture some of these other factors we estimate a gravity model which includes many of the factors shown by the literature to drive portfolio allocations (see Portes and Rey, 2005 and Fidora, Fratzscher and Thimann, 2007) in the form: 
where $\boldsymbol{X}_{i, t}$ represents a vector of country-level controls. The regressions are estimated over our entire sample period of 2004-2017. Control variable definitions are in Appendix Table A2.

Alternative constructions of relative portfolio weights generate different conclusions about factors that influence portfolio preferences. Column 1 of Table 2 shows the coefficients from the estimation of equation (3) when the portfolio weights are constructed on the standard residence basis as in the CPIS. As is typical in the literature, variables proxying for frictions such as country familiarity and financial development are generally significant and with the expected signs: U.S. investors have higher portfolio weights in countries where English is the official language and where broad-band internet access is higher, and lower weights in countries that are more geographically distant. ${ }^{5}$ U.S. investors also have somewhat higher weights in countries with a larger share of equity market capitalization owing to firms in consumer or industrial sectors (the financial sector is the omitted dummy). The "financial center" dummy variable adds a nontrivial 0.4 to the estimated portfolio weight, an effect larger in size than the combined effects of having internet access one standard deviation higher than average, geographic location one standard deviation closer, and using English as an official language. The size and significance of this dummy variable highlights that countrylevel characteristics of financial centers likely have more to do with the choice of firm incorporation than they do to explaining investor preferences.

TABLE 2

\section{FACTORS DRIVING U.S. INVESTOR COUNTRY-LEVEL RELATIVE PORTFOLIO WEIGHTS}

\begin{tabular}{|c|c|c|c|c|c|c|}
\hline \multirow{2}{*}{$\begin{array}{l}\text { Portfolio weight } \\
\text { Internet Use }\end{array}$} & \multicolumn{2}{|c|}{$\begin{array}{c}1 \\
\text { Residence Basis }\end{array}$} & \multicolumn{2}{|c|}{$\begin{array}{c}2 \\
\text { Nationality Basis }\end{array}$} & \multicolumn{2}{|c|}{$\begin{array}{c}3 \\
\text { Revenue-Exposure }\end{array}$} \\
\hline & $0.002 * *$ & $(0.001)$ & $0.001 * *$ & $(0.001)$ & 0.001 & $(0.001)$ \\
\hline English as official language & $0.154 * * *$ & $(0.041)$ & $0.135 * *$ & $(0.035)$ & 0.007 & $(0.051)$ \\
\hline Common legal framework & 0.009 & $(0.035)$ & -0.006 & $(0.031)$ & 0.018 & $(0.048)$ \\
\hline Distance & $-0.102 * *$ & $(0.043)$ & $-0.111 * *$ & $(0.044)$ & $-0.107 * * *$ & $(0.041)$ \\
\hline Listed companies & 0.000 & $(0.014)$ & -0.001 & $(0.013)$ & $-0.032 * *$ & $(0.014)$ \\
\hline Lagged GDP growth & -0.002 & $(0.003)$ & -0.004 & $(0.002)$ & -0.005 & $(0.003)$ \\
\hline $\begin{array}{l}\text { Consumer sector share of country } \\
\text { market }\end{array}$ & $0.227 * *$ & $(0.103)$ & 0.068 & $(0.084)$ & $0.541 * * *$ & $(0.207)$ \\
\hline $\begin{array}{l}\text { Industrial sector share of country } \\
\text { market }\end{array}$ & $0.147 * *$ & $(0.058)$ & $0.199 * * *$ & $(0.055)$ & 0.198 & $(0.157)$ \\
\hline Financial center & $0.437 * * *$ & $(0.132)$ & $0.312 * *$ & $(0.122)$ & $0.142 * *$ & $(0.068)$ \\
\hline Constant & 0.905 & $(0.399)$ & 1.022 & $(0.424)$ & 1.521 & $(0.458)$ \\
\hline $\mathrm{N}$ & 861 & & 861 & & 861 & \\
\hline $\mathrm{F}(9,75)$ & 11.15 & & 17.75 & & 6.12 & \\
\hline Prob $>F$ & 0 & & 0 & & 0 & \\
\hline $\mathrm{R}^{2}$ & 0.555 & & 0.457 & & 0.310 & \\
\hline
\end{tabular}

Estimates of $\beta$ from equation (3). Robust standard errors clustered at the country level in parentheses. Estimates from 2004-2017.

Column 2 repeats the exercise using portfolio weights constructed on a nationality basis. Results are largely similar to the residence-based results, although the financial center dummy is a bit smaller, and the consumer sector share of market capitalization is no longer significant. 
Our understanding of the drivers of portfolio allocation changes when we measure holdings on a revenue-exposure basis. Relatively few of the country-level explanatory variables remain meaningful in explaining portfolio weights (column 3), although distance remains significant at roughly the same magnitude. The consumer sector share also remains significant. However, the overall explanatory power of the regression variables as measured by the $\mathrm{R}^{2}$ drops noticeably.

What does matter is the presence of U.S. multinationals, as suggested in Table 3. Activities of multinationals can provide an additional channel for information about a country, and investor familiarity with "home country" firms specifically provides a further informational advantage. A variable that captures the share of sales revenue generated in a country that owes specifically to U.S. firms has a highly significant and materially important effect in explaining U.S. investor portfolio allocations (column 1). This measure, which is only applicable to the revenue-exposure basis, contributes on average about half of the estimated revenue-exposure portfolio weight, and the size of this effect is about 50 percent higher if the U.S. sales revenue share is one standard deviation higher. The significance of this variable holds in a panel regression with country fixed effects (column 2) and in a panel regression when both country and time effects are included (column 3). These results at the country level are consistent with our findings in Figure 3, which showed that U.S. investors gained considerable indirect overall foreign exposure through their holdings of U.S. multinationals.

TABLE 3

\section{DIVERS OF U.S. INVESTOR COUNTRY-LEVEL RELATIVE PORTFOLIO WEIGHTS, REVENUE-EXPOSURE BASIS}

\begin{tabular}{|c|c|c|c|c|c|c|}
\hline & \multicolumn{2}{|c|}{1} & \multicolumn{2}{|c|}{2} & \multicolumn{2}{|c|}{3} \\
\hline Internet Use & $0.001 *$ & $(0.000)$ & $0.001 * *$ & $(0.000)$ & -0.001 & $(0.001)$ \\
\hline English as official language & $0.063 * *$ & $(0.026)$ & & & & \\
\hline Common legal framework & -0.013 & $(0.022)$ & & & & \\
\hline Distance & $-0.050 * * *$ & $(0.019)$ & & & & \\
\hline Listed companies & -0.001 & $(0.007)$ & -0.020 & $(0.020)$ & -0.009 & $(0.014)$ \\
\hline Lagged GDP growth & $-0.004 * * *$ & $(0.001)$ & -0.001 & $(0.001)$ & 0.000 & $(0.001)$ \\
\hline $\begin{array}{l}\text { Consumer sector share of country } \\
\text { market capitalization }\end{array}$ & $0.314 * * *$ & $(0.101)$ & $0.373 * * *$ & $(0.129)$ & $0.254^{*}$ & $(0.149)$ \\
\hline $\begin{array}{l}\text { Industrial sector share of country } \\
\text { market capitalization }\end{array}$ & $0.242 * * *$ & $(0.082)$ & $0.262 * * *$ & $(0.090)$ & 0.141 & $(0.119)$ \\
\hline Financial center & $0.109 * *$ & $(0.052)$ & & & & \\
\hline $\begin{array}{l}\text { Share of sales revenue from U.S. } \\
\text { firms }\end{array}$ & $1.622 * * *$ & $(0.125)$ & $1.322 * * *$ & $(0.174)$ & $1.674 * * *$ & $(0.253)$ \\
\hline Constant & $0.525 * *$ & $(0.209)$ & 0.213 & $(0.170)$ & 0.141 & $(0.137)$ \\
\hline $\mathrm{N}$ & 861 & & 861 & & 861 & \\
\hline & $F(10,75):$ & 55.7 & $F(6,75):$ & 53.99 & $\mathrm{~F}(18,75):$ & 74.68 \\
\hline Prob $>F$ & 0 & & 0 & & 0 & \\
\hline $\mathrm{R}^{2}$ & 0.765 & & & & & \\
\hline R-sq: & & & & & & \\
\hline within & & & 0.605 & & 0.734 & \\
\hline between & & & 0.730 & & 0.690 & \\
\hline overall & & & 0.690 & & 0.674 & \\
\hline Coutry fixed effects & no & & yes & & yes & \\
\hline Year fixed effects & no & & no & & yes & \\
\hline
\end{tabular}


Table reports estimates of $\beta$ from equation (3). Robust standard errors clustered at the country level in parentheses. Estimates from 2004-2017.

These results suggest that country-level characteristics that matter for investor portfolio allocations may additionally enter indirectly, through the choices multinational firms make about which markets to enter and where to concentrate their activities, and the informational advantages that investors gain through activities of multinational firms, especially those of firms from the same home country. They also suggest that country-level aggregate measures of portfolio returns and correlations may be insufficient to explain investor portfolio allocations across countries. Richer analysis that takes into account firm-level characteristics, returns, and correlations are likely to be more informative.

\section{CONCLUSION}

In this paper we demonstrated the weaknesses of standard measures of cross-border portfolio investment as a proxy for geographic exposure. Our findings have important implications for any work in international finance which relies on these data and should be of interest to academics, policy makers, and global investors. Our improved exposure measures could possibly change our understanding of the drivers of capital flows, exchange rate movements, and global asset returns more generally. In future work we will use our improved exposure measures to explore these and other important topics.

\section{ENDNOTES}

1. For this exercise focusing on the U.S. investor equity portfolio, our residence-to-nationality remapping only affects equity of foreign firms, as all of the common stock equity identified as "U.S." in the TIC system is also identified as "U.S." by standard benchmarks such as the MSCI. The mapping would be less straightforward if we were to extend our analysis to the U.S. bond portfolio, because debt issued by U.S.resident financing subsidiaries with foreign parents are included as "U.S." bonds by TIC.

2. Worldscope defines their geographic sales variable as "represents the total revenues from the geographic region updated in the respective description."

3. This methodology for allocating geographic revenue is similar in spirit to Amenc, et.al., (2015) and also to Morningstar's "Revenue Exposure by Region." See Appendix Table A1 for more details on methodology. For firms not reported in Worldscope or with incomplete information, we use data from Bloomberg and from company annual reports where possible to determine market capitalization and sales revenue allocations.

4. By comparison, the World Bank's World Development indicators lists global equity market capitalization for 2018 at $\$ 68.6$ trillion. In terms of foreign-issued equity held by U.S. investors, we are able to match more than $80 \%$ of the market value of foreign common stock held in the early $2000 \mathrm{~s}$, increasing to more than $90 \%$ by 2009 .

5. Similar results (not shown) hold for alternative measures of financial development or if the share of U.S. trade in country $i$ is substituted for distance. Variables capturing aspects of portfolio returns (such as the correlation of country equity market returns with U.S. market returns, or GDP growth with U.S. growth) are generally insignificant in these regressions.

\section{REFERENCES}

Ahearne, A.G., Griever, W.L., \& Warnock, F.E. (2004). Information costs and home bias: An analysis of U.S. holdings of foreign equities. Journal of International Economics, 62(2), 313-336.

Amenc, N., Goltz, F., Sivasubramanian, S., \& Lodh, A. (2015). Robustness of smart beta strategies. The Journal of Index Investing, 6(1), 17-38.

Amiti, M., Kong, S.H., \& Weinstein, D. (2020). The effect of the U.S. - China trade war on U.S. investment. NBER Working Paper No. 27114.

Bertaut, C.C., Bressler, B., \& Curcuru, S.E. (2019). Globalization and the Geography of Capital Flows. FEDS Notes 2019-09-06, Board of Governors of the Federal Reserve System (U.S.). 
Cai, F., \& Warnock F.E. (2012). Foreign exposure through domestic equities. Finance Research Letters, 9(1), 8-20.

Coppola, A., Maggiori, M., Neiman, B., \& Schreger, J. (2021). Redrawing the map of global capital glows: The role of cross-border financing and tax havens. Quarterly Journal of Economics, 136(3), 1499-1556.

Coeurdacier, N., \& Rey, H. (2013). Home bias in open economy financial Macroeconomics. Journal of Economic Literature, 51(1), 63-115.

Fidora, M., Fratzscher, M., \& Thimann, C. (2007). Home bias in global bond and equity markets: The role of real exchange rate volatility. Journal of International Money and Finance, 26(4), 631635.

Portes, R., \& Rey, H. (2005). The determinants of cross-border equity flows. Journal of International Economics, 65, 269-296.

U.S. Department of Treasury. (n.d.). Annual reports on U.S. Portfolio Surveys of Foreign Securities, various years. Retrieved from https://www.treasury.gov/resource-center/data-chartcenter/tic/Pages/shcreports.aspx

\section{APPENDIX}

TABLE A1

DESCRIPTION OF THE GEOGRAPHIC SEGMENT ALLOCATION FOR FIRM SALES

For each geographic segment provided for location of sales revenue, we calculate the share of total sales revenue attributable to that segment, and then use each share to allocate market capitalization exposures and U.S. portfolio exposures. When geographic segments list individual countries, we assign sales shares to that particular country. When geographic segment data lists regions or combinations of countries, we allocate across countries by GDP shares. If no geographic segment data is listed, we assume all sales are domestic. When sales data is missing in one year, we use the prior year sales shares.

TABLE A2

CONTROL VARIABLES USED IN THE RELATIVE WEIGHT ESTIMATION

\begin{tabular}{lrr}
\hline & & $\begin{array}{c}\text { Standard } \\
\text { Deviation }\end{array}$ \\
\cline { 2 - 3 } $\begin{array}{l}\text { Internet use: Percentage of individuals using the internet in each country each } \\
\text { year. Source: WDI database. }\end{array}$ & 53.53 & 27.27 \\
$\begin{array}{l}\text { English as official language: Dummy variable indicating whether country shares } \\
\text { an official language with the US. Source: CEPII's Language database. }\end{array}$ & 0.25 & 0.43 \\
$\begin{array}{l}\text { Common legal framework: Dummy variable indicating whether the country has } \\
\text { shared legal origins with the US. }\end{array}$ & 0.30 & 0.46 \\
$\begin{array}{l}\text { Distance: Log of geographic distance between New York City and the largest } \\
\text { city in each country. }\end{array}$ & 9.10 & 0.40 \\
$\begin{array}{l}\text { Listed companies: log of the number of listed companies in each country each } \\
\text { year. Source: World Bank Financial Structure Database }\end{array}$ & 6.98 & 1.39 \\
Lagged GDP growth: country year-on-year GDP growth in the previous year. & 3.54 & 3.70 \\
\hline
\end{tabular}


Consumer sector share of country market capitalization: share of market capitalization from firms in apparel, food \& beverages, health care, electronics, pharmaceutical, publishing, retail, recreation, or tobacco industries in each country each year. Source: Authors' calculations from Worldscope data.

$0.18 \quad 0.20$

Industrial sector share of country market capitalization: share of market capitalization from firms in aerospace, automotive, chemical, construction, electrical, machinery, oil and other commodities, paper production, transportation, and utilities industries in each country each year. Source: Authors' calculations from Worldscope data.

$0.53 \quad 0.24$

Financial center: Dummy variable for countries Bahamas, Bermuda, British Virgin Islands, Cayman Islands, Curacao/Netherlands Antilles, Ireland, Luxembourg, Netherlands, and Switzerland.

$0.08 \quad 0.27$

Share of sales revenue from U.S. firms: share of total sales reported by U.S. (by nationality) firms in each country each year. Authors' calculations from Worldscope data.

$0.17 \quad 0.09$

